\title{
Enhancement effects of ethanolic extract of Fagonia cretica on Bisphenol A (BPA)- induced genotoxicity and biochemical changes in rats
}

Omaima Mohamed Abd-El-Moneim', Abeer Hamdy Abd El-Rahim", Amira Abd El Raouf Mohamed', Ibrahim Mohamed Farag ${ }^{1}$ and Aboelfetoh Mohamed Abdalla ${ }^{2}$

\begin{abstract}
Background: Fagonia cretica L. was considered to be a medical plant that was used for the treatment of different diseases, so the current study was designed to clarify whether Fagonia cretica extract (FCE) can avoid Bisphenol A (BPA)-induced genotoxicity and biochemical alterations in rats. Sixty-three male rats were used in this experiment. These animals were distributed into nine groups (seven rats each): negative control, control of corn oil, positive control that were administrated BPA in corn oil $(10 \mathrm{mg} / \mathrm{kg}$. b.w.) for 3 weeks, three protection groups received the same dose of BPA in corn oil at the same period together with FCE $(3.3,4.2$ and $5.0 \mathrm{~g} / \mathrm{kg})$ daily for 3 weeks, and three therapeutic groups received FCE alone at the same doses for 10 days after cessation of BPA treatment. Genetic and biochemical studies were conducted. Genetic studies involved DNA comet assay, micronucleus test, chromosome examination, and mitotic index analysis. Biochemical studies involved liver function (AST, ALT, ALph, and Bilirubin), kidney function (urea and creatinine contents), protein profile, MDA, and endogenous antioxidative system (SOD, CAT, and ACHE) as well as nucleic acid (DNA and RNA) contents in the liver, kidney, and brain tissues.
\end{abstract}

Results: The results demonstrated that the treatment with BPA induced a significant elevation in genetic abnormalities and deleterious effects in biochemical parameters in relation to untreated control. FCE treatment was found to be significantly diminished the massive damage in the genetic constituents and dangerous alterations in biochemical parameters with respect to BPA treatment alone. These enhancements were increased by increasing the dose level of FCE. Moreover, better results were clarified by utilizing FCE as a protective agent than its utilization as a therapeutic agent especially by using the high dose $(5.0 \mathrm{~g} / \mathrm{kg})$, in which mostly genetic and biochemical alterations were observed to be restored towards natural levels.

Conclusions: These findings clarified a new insight into the protective effect of FCE in minimizing BPA-induced genotoxicity and biochemical changes in rats detecting the capability of such medicinal plant for alleviating the adverse effect of BPA.

Keywords: Bisphenol A, Fagonia cretica, Genetics, Biochemistry, Rats

\footnotetext{
*Correspondence: abeerabdel_rahim@yahoo.com

${ }^{1}$ Departments of Cell Biology, National Research Centre, Dokki, Cairo, Egypt

Full list of author information is available at the end of the article
}

\section{Springer Open}

(c) The Author(s). 2020 Open Access This article is licensed under a Creative Commons Attribution 4.0 International License, which permits use, sharing, adaptation, distribution and reproduction in any medium or format, as long as you give appropriate credit to the original author(s) and the source, provide a link to the Creative Commons licence, and indicate if changes were made. The images or other third party material in this article are included in the article's Creative Commons licence, unless indicated otherwise in a credit line to the material. If material is not included in the article's Creative Commons licence and your intended use is not permitted by statutory regulation or exceeds the permitted use, you will need to obtain permission directly from the copyright holder. To view a copy of this licence, visit http://creativecommons.org/licenses/by/4.0/. 


\section{Introduction}

Bisphenol A (BPA) was found to be a chemical component that widely used and spread in the polycarbonate plastic manufacture and epoxy resins for several years (Hunt et al., 2003; Allard and Colaiacovo, 2010; Strong et al., 2016). This component has a major application in the plastic food products, beverage containers baby bottles, coating of food cans, medical devices, and dental secants ( Eid et al., 2015; Aghajanpour- Mir et al. ., 2016). So, people of different ages were observed to be inevitably exposed to BPA in daily life. Moreover, BPA was detected in different environmental samples involving dust, sewage, water, indoor and outdoor air (Vandenberg et al., 2007). Several studies reported that BPA was observed in the human amitotic fluid (Ikezuki et al., 2002), breast milk (Sun et al., 2004), human placenta (Schonfelder et al., 2002), cord blood (Wan et al., 2010), and fetal liver (Cao et al., 2012). However, the exposure to BPA was revealed to be accompanied by inducing serious environmental pollution and causing adverse effects on human and animal health (Eid et al., 2015). The hazardous or the adverse effects of BPA were detected to be associated with different diseases such as diabetes, neurobehavioral, abnormal karyotypes (Vandenberg et al., 2007; Haighton et al., 2012; Mirmira and Evans-Molina, 2014; Aghajanpour-Mir et al., 2016), inflammatory cytokine dysregulation (Ben- Jonathan et al., 2009), and mitochondrial-mediated apoptosis in the hepatic tissue (Xia et al., 2014). Thus, scientific attempts must be considered to face the adverse effect of BPA. Natural products especially the extractions of medical plants are essential to save materials that are preferred for using against the hazardous effects of different toxicants.

The plant Fagonia cretica L. was considered to be a member of the family Zygophyllaceae (Hussain et al., 2007). The distribution of such plant species in Egypt is mostly found in the Mediterranean Coastal region (for example, Ras El Hikma, Burg El Arab). A concise description is given as a glabrous plant with prostrate quadrangular branches, small spiny undershrub (Shalaby, 1958; Sharkawy, 1961). In the scientific and folkloric literature, Fagonia cretica $L$. is reputed to be a medical plant that is used for the treatment of different diseases such as tumor, cancer, fever, thirst, vomiting, asthma, dysentery, liver trouble, stomach troubles, and skin diseases (Hussain et al., 2007). Moreover, Fagonia cretica has other effects including analgesic, anti-inflammatory, and antipyretic activities ( Puri and Bhandari, 2014). Fagonia cretica has been reported to contain many antioxidant constitutions such as flavonoids, alkaloids, saponins, terpenoids, sterols, coumarins, proteins, and amino acids (Saleh et al., 2011; Puri and Bhandari, 2014). So, the present work was designed to study the protective and therapeutic effects against BPA-induced genotoxicity and biochemical changes in rats. Genetic studies involved DNA comet assay, micronucleus test, chromosome examination, and mitotic index analysis. Biochemical parameters included superoxide dismutase (SOD), catalase (CAT), malondialdehyde (MDA), acetylcholinesterase (ACHE), liver function, and kidney function. Also, nucleic acid (DNA and RNA) contents in the liver, kidney, and brain tissues were investigated.

\section{Materials and methods}

\section{Chemicals}

Bisphenol A (BPA) was purchased from Sigma (St. Louis, Mo, USA). BPA, a water-insoluble powder was dissolved in corn oil, for daily uptake by gastric gavage to rat animals. A total of $5 \mathrm{~g}$ of BPA were dissolved in $500 \mathrm{ml}$ corn oil (as $1 \% \mathrm{v} / \mathrm{w}$ ). BPA doses: dose of $10 \mathrm{mg} /$ kg.b.w. were selected based on the National Toxicology Program, 1985, 2008.

\section{Plant material}

Fagonia cretica L. had been collected in March 2018 from Burg El Arab desert region and identified in the Department of Horticultural Crop Technology, National Research Centre, Egypt. Fresh aerial parts of this plant were rinsed with distilled water and kept under shade till drying.

\section{Preparation of extract of Fagonia cretica (FCE)}

According to the method of Hussain et al. (2007), extraction was carried out by a simple maceration process. Aerial parts $(490 \mathrm{~g})$ were ground and merged in $3.5 \mathrm{~L}$ ethanol. Homogenate was kept for 4 weeks at room temperature $\left(25 \pm 2{ }^{\circ} \mathrm{C}\right)$ in the extraction bottle. After 4 weeks, the mixture was filtered twice, first using ordinary filter paper and then Whatman-41 filter paper. Ethanol was completely evaporated at room temperature. In total, $21 \mathrm{~g}$ dried ethanolic extract of aerial parts was obtained.

\section{Experimental animals}

Male albino rats of Sprague-Dawley strain weighing about $120 \mathrm{~g}$ were obtained from the Animal House, National Research Centre, Egypt. Animals were housed at an ambient temperature of $25 \pm 3.2^{\circ} \mathrm{C}$ on light/dark cycle of $12 / 12 \mathrm{~h}$. All rats were kept in clean polypropylene cages and administered food and water ad libitum.

All experimental procedures involving animals were conducted in accordance with the ethical guidelines of the Medical Ethical Committee of the National Research Centre in Egypt (IAEC, 2010). 


\section{Experimental design}

A total of 63 rats were used and divided into 9 equal groups $(\mathrm{G})$ :

G1 (control group) received only a basal diet for 3 weeks.

G2 (oil group) received a basal diet and gavage (orally) corn oil $(10 \mathrm{mg} / \mathrm{kg}$.b.w.) daily for 3 weeks.

G3 (BPA group) received (orally) BPA in corn oil at a dose of $10 \mathrm{mg} / \mathrm{kg}$. b.w. daily for 3 weeks.

G 4-6 received (orally) BPA in corn oil in the same dose and way previously mentioned. Starting on the first day of BPA administration, rats in 4-6 groups were treated (orally) daily for 3 weeks with FCE $(3.3 \mathrm{~g} / \mathrm{kg}$., 4.2 $\mathrm{g} / \mathrm{kg}$., and $5.0 \mathrm{~g} / \mathrm{kg}$., respectively). These groups (4-6) were used to evaluate the protective role of FCE against the toxicity of BPA.

G 7-9 received (orally) BPA in corn oil in the same dose and way previously mentioned and for the same period, and then the rat groups were treated (orally) with FCE $(3.3 \mathrm{~g} / \mathrm{kg}$., $4.2 \mathrm{~g} / \mathrm{kg}$., and $5.0 \mathrm{~g} / \mathrm{kg}$., respectively) for 10 days. These groups (7-9) were used to evaluate the therapeutic effect of FCE against BPA toxicity.

\section{DNA comet assay}

Comet assay was performed referring to the protocol mentioned previously by Blasiak et al. (2004). The rat liver cells of each treatment were mixed with lowmelting-point agarose (ratio of 1:10 v/v), then pipetted to precoated slides with normal-melting-point agarose. The slides were kept flat at $4{ }^{\circ} \mathrm{C}$ for $30 \mathrm{~min}$ in a dark environment. The third layer of low-melting-point agarose was then pipetted on slides, left to solidify at for $30 \mathrm{~min}$ at $4{ }^{\circ} \mathrm{C}$. The slides were transferred to a pre-chilled lysis solution, kept for $60 \mathrm{~min}$ at $4{ }^{\circ} \mathrm{C}$. After that, slides were immersed in freshly prepared alkaline unwinding solution at room temperature in the dark for $60 \mathrm{~min}$. Slides were subjected to electrophoresis run at $25 \mathrm{~V}, 300 \mathrm{~m}$ Amps at $4{ }^{\circ} \mathrm{C}$ for $30 \mathrm{~min}$. The slides were rinsed in neutralizing solution followed by immersion in $70 \%$ ethanol and then air-dried. Ethidium bromide was used for slides stain then and visualized by using Zeiss epifluorescence microscope $(510-560 \mathrm{~nm}$, barrier filter $590 \mathrm{~nm})$ with a magnification of $400 \times$. For each animal, about 100 cells were examined to determine the percentage of cells with DNA damage that appear like comets. The nonoverlapping cells were randomly selected and were visually assigned a score on an arbitrary scale of $0-3$ (i.e., class $0=$ no detectable DNA damage and no tail; class 1 $=$ tail with a length less than the diameter of the nucleus; class $2=$ tail with length between $1 \times$ and $2 \times$ the nuclear diameter; and class $3=$ tail longer than $2 \times$ the diameter of the nucleus) based on perceived comet tail length migration and relative proportion of DNA in the nucleus (Collins et al., 1997).

\section{Cytogenetic analyses \\ Micronucleus test}

Bone marrow slides were prepared according to the method described by Krishna and Hayashi (2000). The bone marrow was washed with $1 \mathrm{ml}$ of fetal calf serum and then smeared on clean slides. The slides were left to air dry and then fixed in methanol for $5 \mathrm{~min}$, followed by staining in May-Grunwald-Giemsa for $5 \mathrm{~min}$ then washed in distilled water and mounted. For each animal, 2000 polychromatic erythrocytes (PCEs) were examined for the presence of micronuclei.

\section{Chromosome preparation}

For chromosome analysis, both treated and control animals were sacrificed by cervical dislocation at the end of the experiment. One hour and a half or $2 \mathrm{~h}$ before sacrifice, rats were injected i.p. with $0.5 \mathrm{~g}$ colchicine $/ \mathrm{kg}$. b.w. The femurs were removed and the bone marrow cells were aspirated using saline solution. Metaphase spreads were prepared using the method of Preston et al. (1987). Fifty metaphase spreads per animal were analyzed for scoring the different types of chromosome aberrations.

\section{Mitotic index}

Mitotic index was determined by scoring at least 1000 cells from each animal, and then MI was calculated by a ratio of mitotic cells to total cell number in 1000 cells of each rat, then the coefficient of division is obtained according to the following formula: mitotic index (\%) = the number of the dividing cells $\times 100 /$ the total number of cells (Shubber and Juma, 1999.)

\section{Biochemical study}

At the end of the first stage (protection treatment) and the end of the second stage (therapeutic treatment), blood samples were collected and centrifuged at $3000 \mathrm{~g}$ to obtain the serum for the determination aspartate transaminase (AST), alanine transaminase (ALT), and alkaline phosphate (ALPh) (according to Steven, 1996; Scandinatvien, Socrety 1974; Walter and Gerade, 1970, respectively) as indicators of liver functions. The levels of urea (Fawcett and Soctt, 1960) and creatinin (Bartles and Bohmer, 1972) were also determined as kidney function. Serum protein profile, as well as endogenous lipid peroxidation (MDA) and antioxidant system including superoxide dismutase (SOD), catalase (CAT) and acetylcholinesterase (ACHE) were determined according to Ohkama et al. (1979), Nishikimi et al. (1972), Aebi (1984) and Henry (1974), respectively.

Moreover, nucleic acid (DNA and RNA) contents were determined in the liver, kidney and brain tissues according to Pearse (1985). 


\section{Statistical analysis}

Statistical analysis was carried out with SPSS software. Data were analyzed using a one-way analysis of variance (ANOVA) followed by Duncan's post hoc test for comparison between different treatments. The values were expressed as mean \pm S.E. and differences were considered significant when $P<0.05$.

\section{Results}

\section{Comet assay of DNA}

The results of the present work (Fig. 1 and Table 1) clarified significant increases $(P<0.01)$ of DNA damage in rats that exposed to BPA as compared to those found in the normal control group. In the protective treatments with FCE, the present findings showed a decrease in the values of DNA damage induced by exposure to BPA. The DNA damage decreased by increasing the level of FCE dose, where the statistical analysis exhibited a slight decrease in the DNA damage using low dose ( $3.3 \mathrm{~g} / \mathrm{kg} . \mathrm{b} . w$.$) , while the DNA damage significantly low-$ ered by using medium ( $4.2 \mathrm{~g} / \mathrm{kg}$.b.w.) or high $(5.0 \mathrm{~g} /$ kg.b.w.) doses. The highest dose $(5.0 \mathrm{~g} / \mathrm{kg}$.b.w.) caused the lowest values of DNA damage. On the other hand, the results of therapeutic treatments with three doses (3.3, 4.2, and $5.0 \mathrm{~g} / \mathrm{kg})$ of FCE displayed insignificant decreases of DNA damage produced by exposure to BPA, in spite of these decreases of DNA damage were shown to be increased by increasing the dose level. Moreover, the BPA-intoxicated rats that were treated with a high dose had the lowest value of DNA damage.

\section{Micronucleus test}

The results of the present experiment (Fig. 2 and Table 2) showed significant elevation in values of micronucleated polychromatic erythrocytes (MNPCE) in the rats that exposed to BPA relation to that of unexposed normal control. In the male rat groups that were exposed to BPA and received FCE doses as protective or therapeutic agents, the induced values of MNPCE significantly reduced as compared to the male rat group that was treated with BPA alone. This reduction of induction of MNPCE was increased by increasing the dose level of FCE. The present findings displayed that the treatment with a high dose $(5.0 \mathrm{~g} / \mathrm{kg}$.b.w.) produced the lowest value of MNPCE. Moreover, the utilizing of FCE as a protective agent especially by using the highest dose ameliorated more the genetic material recovery (by decreasing the induced values of MNPCE) and resulted in the best results than the utilization of FCE as a therapeutic agent.

\section{Chromosome examination}

The reported data of the present results (Table 3) revealed that the treatment with BPA had induced a highly significant elevation in the frequencies of chromosome aberrations comparing with the control group. The male rat groups that were treated with BPA and gavages the FCE doses as protective or therapeutic agents had a significant reduction of the frequencies of chromosome aberrations in relation to the rat group that was treated with BPA alone. The reduction in the frequencies of chromosome aberrations was found to be increased by increasing the dose level of FCE. The present data exhibited that the utilizing of the highest dose $(5.0 \mathrm{~g} / \mathrm{kg}$.b.w. $)$ of FCE as a protective or therapeutic agent gave the lowest values of the frequencies of chromosome aberrations. Furthermore, the utilization of FCE as a protective agent especially by using the highest dose led to more amelioration in the genetic material recovery by decreasing the
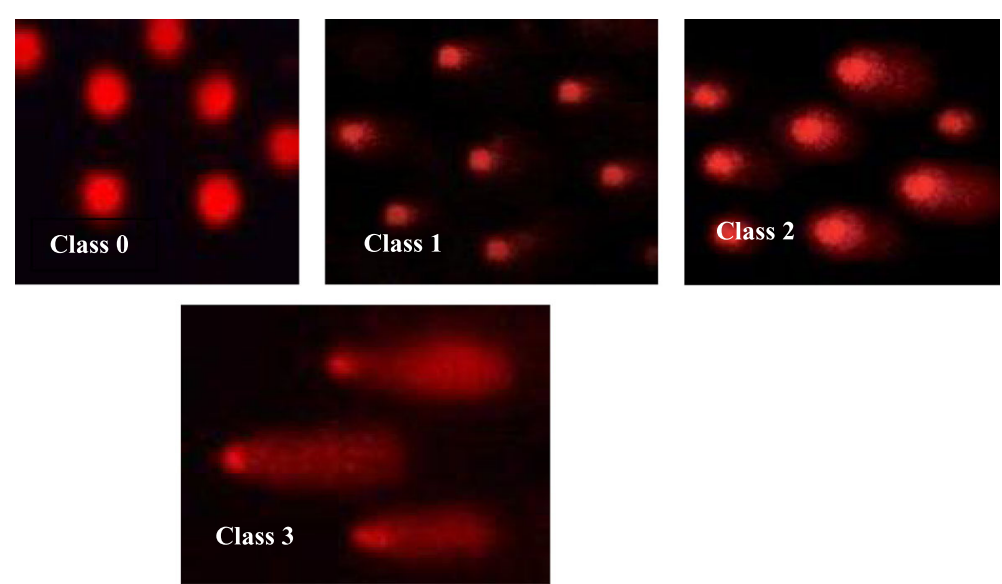

Fig. 1 Shows photographs of the comet assay classes of extended DNA damage in the rat liver. The examination of the varying extent of DNA damage in normal control, BPA-intoxicated rats, protection groups of FCE, and therapeutic groups of FCE was recorded in Table 1 . Class $0=$ no tail; class 1 = tail length < diameter of the nucleus; class $2=$ tail length between $1 \times$ and $2 \times$ the diameter of the nucleus; and class $3=$ tail length $>2 \times$ the diameter of the nucleus 
Table 1 Comet assay analysis shows the enhancement role of Fagonia cretica (FCE) on Bisphenol A-induced DNA damage in rats

\begin{tabular}{|c|c|c|c|c|c|c|c|c|}
\hline \multirow[t]{2}{*}{ Treatment } & \multirow{2}{*}{$\begin{array}{l}\text { No of } \\
\text { animals }\end{array}$} & \multirow{2}{*}{$\begin{array}{l}\text { No. of } \\
\text { analyzes } \\
\text { cells* }\end{array}$} & \multirow[t]{2}{*}{ Comets } & \multicolumn{4}{|c|}{ Comet classes $^{* *}$} & \multirow{2}{*}{$\begin{array}{l}\text { DNA damaged } \\
\text { cells } \% \\
\text { (mean } \pm \text { SEM) }\end{array}$} \\
\hline & & & & 0 & 1 & 2 & 3 & \\
\hline Normal control & 5 & 500 & 31 & 469 & 19 & 12 & 0 & $6.2 \pm 1.30^{c}$ \\
\hline Control oil treatment & 5 & 500 & 34 & 466 & 21 & 13 & 0 & $6.8 \pm 1.30^{c}$ \\
\hline Bisphenol A (BPA) & 5 & 500 & 139 & 361 & 42 & 53 & 44 & $27.8 \pm 2.59^{\mathrm{a}}$ \\
\hline Protective low dose of FCE & 5 & 500 & 124 & 376 & 36 & 42 & 46 & $24.8 \pm 0.84^{a}$ \\
\hline Protective medium dose of FCE & 5 & 500 & 86 & 414 & 31 & 26 & 29 & $17.2 \pm 1.92^{\mathrm{b}}$ \\
\hline Protective high dose of FCE & 5 & 500 & 77 & 423 & 28 & 27 & 22 & $15.4 \pm 2.61^{b}$ \\
\hline Therapeutic low dose of FCE & 5 & 500 & 126 & 374 & 39 & 45 & 42 & $25.2 \pm 1.92^{\mathrm{a}}$ \\
\hline Therapeutic medium dose of FCE & 5 & 500 & 113 & 387 & 34 & 44 & 35 & $22.6 \pm 1.52^{\mathrm{ab}}$ \\
\hline Therapeutic high dose of FCE & 5 & 500 & 106 & 394 & 31 & 38 & 37 & $21.2 \pm 1.64^{\mathrm{ab}}$ \\
\hline
\end{tabular}

${ }^{*}$ Number of cells examined per a group, ${ }^{* *}$ Class $0=$ no tail; Class $1=$ tail length $<$ diameter of the nucleus; Class $2=$ tail length between $1 \times$ and $2 \times$ the diameter of the nucleus; and Class $3=$ tail length $>2 \times$ the diameter of the nucleus

All data are expressed as mean \pm SE. Means with different superscripts letters a, b, c are significantly different at $P \leq 0.05$

chromosome damages and resulted in better findings than the utilization of FCE as a therapeutic agent.

\section{Mitotic index}

In the present experiment, the mitotic index results (Table 4 and Fig. 3 ) showed a significant mitotic delay $(P$ $<0.01)$ in the BPA-intoxicated rats relation to that of the normal control group. Whereas in the protective treatment, FCE doses gave elevation in the mitotic activity, this elevation was statistically insignificant at low dose treatment as compared to the BPA treatment alone. However, the mitotic activity was significantly increased in BPA-intoxicated rats that treated with medium $(P<$ $0.05)$ or high $(P<0.01)$ doses of FCE with respect to those of BPA treatment alone. The treatment with the highest dose $(5.0 \mathrm{~g} / \mathrm{kg}$.b.w.) of FCE recovered the mitotic

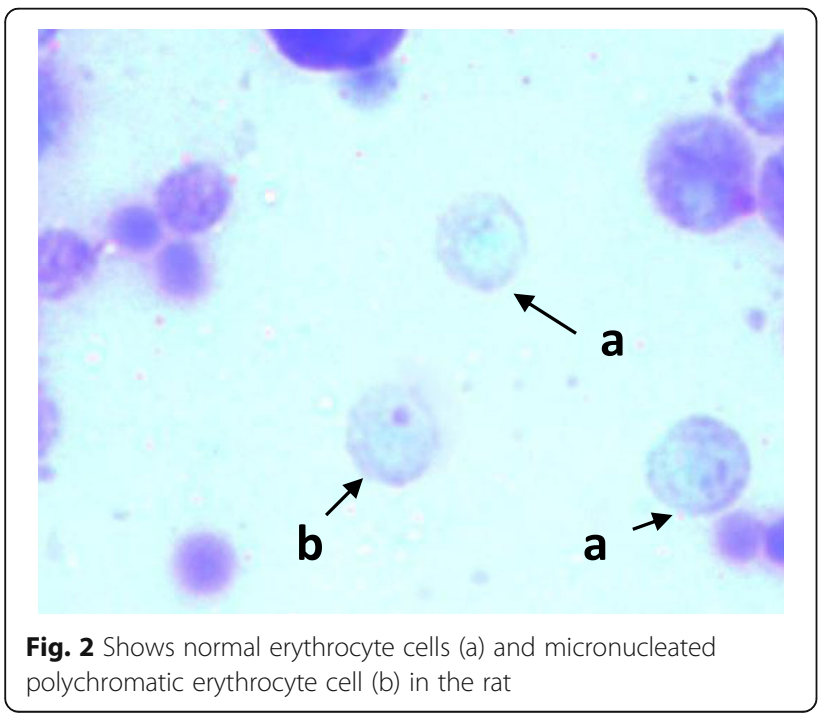

activity to the approximate baseline of normal control. In the therapeutic treatment, the present findings showed no improvement in the mitotic activity by using the low dose of FCE. However, in treatment with medium or high doses of FCE for BPA-intoxicated rats, the mitotic activities were enhanced, this enhancement was insignificant by utilizing the medium dose of FCE treatment and significant $(P<0.05)$ by using the high dose of FCE treatment in relation to that of BPA treatment alone.

\section{Biochemical analysis}

The results of biochemical study (Table 5) showed that the administration of BPA to rats significantly decreased the total protein as well as reduced the SOD, CAT, and ACHE activities as compared to the control group. In

Table 2 Shows the enhancement role of Fagonia cretica extract (FCE) on Bisphenol A-induced micronucleated polychromatic erythrocytes (MNPCE) in rats

\begin{tabular}{ll}
\hline Treatment & MNPCE \\
\hline Normal control & $6.0 \pm 0.55^{\mathrm{g}}$ \\
Control oil treatment & $5.40 \pm 0.68^{\mathrm{g}}$ \\
Bisphenol A (BPA) & $36.20 \pm 1.20^{\mathrm{a}}$ \\
Protective low dose of FCE & $27.60 \pm 0.81^{\mathrm{bc}}$ \\
Protective medium dose of FCE & $22.80 \pm 0.97^{\mathrm{d}}$ \\
Protective high dose of FCE & $13.60 \pm 0.75^{\mathrm{f}}$ \\
Therapeutic low dose of FCE & $29.80 \pm 0.58^{\mathrm{b}}$ \\
Therapeutic medium dose of FCE & $62.20 \pm 0.74^{\mathrm{c}}$ \\
Therapeutic high dose of FCE & $20.0 \pm 0.89^{\mathrm{e}}$ \\
\hline
\end{tabular}

All data are expressed as mean $\pm \mathrm{SE}$. Means with different superscripts letters $\mathrm{a}, \mathrm{b}, \mathrm{c}, \mathrm{d}, \mathrm{e}, \mathrm{f}, \mathrm{g}$ are significantly different at $P \leq 0.05$ 
Table 3 Shows the enhancement role of Fagonia cretica extract (FCE) on Bisphenol A-induced chromosomal aberrations in rats

\begin{tabular}{|c|c|c|c|c|c|c|c|c|}
\hline \multirow[t]{2}{*}{ Treatment } & \multicolumn{6}{|c|}{ Structural chromosomal aberrations } & \multirow[t]{2}{*}{ Aneuploidy } & \multirow{2}{*}{$\begin{array}{l}\text { Total } \\
\text { aberrations }\end{array}$} \\
\hline & Gap & Break & Deletion \& fragment & $\begin{array}{l}\text { Centromeric } \\
\text { attenuation }\end{array}$ & Endomitosis & $\overline{\text { Total structural }}$ & & \\
\hline Normal control & $1.0 \pm 0.32^{d}$ & $0.40 \pm 0.24^{f}$ & $0.40 \pm 0.25^{\mathrm{d}}$ & $0.60 \pm 0.40^{\mathrm{e}}$ & $0.20 \pm 0.20^{d}$ & $2.60 \pm 0.81^{f}$ & $0.60 \pm 0.25^{d}$ & $3.20 \pm 0.80^{f}$ \\
\hline Control oil treatment & $1.20 \pm 0.37^{d}$ & $0.80 \pm 0.37^{\mathrm{ef}^{\mathrm{f}}}$ & $0.40 \pm 0.25^{d}$ & $1.0 \pm 0.45^{e}$ & $0.60 \pm 0.25^{c d}$ & $4.0 \pm 0.44^{f}$ & $0.60 \pm 0.25^{d}$ & $4.60 \pm 0.51^{f}$ \\
\hline Bisphenol A (BPA) & $5.40 \pm 0.75^{\mathrm{a}}$ & $3.60 \pm 0.51^{\mathrm{a}}$ & $4.80 \pm 0.74^{\mathrm{a}}$ & $7.20 \pm 0.37^{a}$ & $3.0 \pm 0.32^{\mathrm{a}}$ & $24.0 \pm 1.22^{\mathrm{a}}$ & $5.40 \pm 0.68^{\mathrm{a}}$ & $29.40 \pm 0.68^{\mathrm{a}}$ \\
\hline $\begin{array}{l}\text { Protective low dose } \\
\text { of FCE }\end{array}$ & $2.80 \pm 0.37^{c}$ & $2.20 \pm 0.20^{\mathrm{bcd}}$ & $1.40 \pm 0.40^{c d}$ & $5.40 \pm 0.51^{b}$ & $2.20 \pm 0.49^{\mathrm{ab}}$ & $14.0 \pm 0.63^{\mathrm{cd}}$ & $3.40 \pm 0.40^{b}$ & $17.40 \pm 0.51^{c}$ \\
\hline $\begin{array}{l}\text { Protective medium } \\
\text { dose of FCE }\end{array}$ & $2.80 \pm 0.20^{c}$ & $1.80 \pm 0.37^{\mathrm{cde}}$ & $1.40 \pm 0.25^{\mathrm{cd}}$ & $4.40 \pm 0.40^{\mathrm{bc}}$ & $2.0 \pm 0.32^{\mathrm{ab}}$ & $12.0 \pm 0.63^{d}$ & $2.40 \pm 0.51^{b c}$ & $14.40 \pm 0.81^{d}$ \\
\hline $\begin{array}{l}\text { Protective high } \\
\text { dose of FCE }\end{array}$ & $2.0 \pm 0.32^{c d}$ & $1.20 \pm 0.37^{\text {def }}$ & $1.0 \pm 0.32^{c d}$ & $2.40 \pm 0.51^{d}$ & $1.60 \pm 0.51^{b c}$ & $8.60 \pm 0.87^{e}$ & $1.80 \pm 0.37^{\mathrm{cd}}$ & $10.40 \pm 1.0^{e}$ \\
\hline $\begin{array}{l}\text { Therapeutic low } \\
\text { dose of FCE }\end{array}$ & $5.0 \pm 0.32^{\mathrm{ab}}$ & $3.0 \pm 0.45^{\mathrm{ab}}$ & $4.20 \pm 0.37^{\mathrm{ab}}$ & $3.40 \pm 0.40^{c d}$ & $2.40 \pm 0.51^{\mathrm{ab}}$ & $18.0 \pm 1.18^{b}$ & $5.20 \pm 0.66^{a}$ & $23.20 \pm 0.86^{b}$ \\
\hline $\begin{array}{l}\text { Therapeutic medium } \\
\text { dose of FCE }\end{array}$ & $4.0 \pm 0.32^{b}$ & $2.60 \pm 0.26^{\mathrm{abc}}$ & $3.20 \pm 0.20^{b}$ & $3.0 \pm 0.55^{d}$ & $3.0 \pm 0.32^{a}$ & $15.60 \pm 0.75^{\mathrm{bc}}$ & $3.60 \pm 0.51^{b}$ & $18.80 \pm 0.86^{c}$ \\
\hline $\begin{array}{l}\text { Therapeutic high } \\
\text { dose of FCE }\end{array}$ & $2.20 \pm 0.37^{c d}$ & $2.20 \pm 0.37^{\mathrm{bcd}}$ & $2.0 \pm 0.32^{c}$ & $2.60 \pm 0.40^{d}$ & $2.80 \pm 0.20^{\mathrm{a}}$ & $11.80 \pm 1.0^{d}$ & $2.60 \pm 0.51^{b c}$ & $14.40 \pm 0.41^{d}$ \\
\hline
\end{tabular}
dose of FCE

All data are expressed as mean \pm SE. Means with different superscripts letters $\mathrm{a}, \mathrm{b}, \mathrm{c}, \mathrm{d}, \mathrm{e}, \mathrm{f}$ are significantly different at $P \leq 0.05$

contrast, the level of MDA was significantly elevated in BPA-intoxicated rats than those found in untreated rats.

In the male rat groups that were treated with BPA and gavage. The FCE doses as protective or therapeutic agents, the harmful effects of above biochemical parameters were significantly alleviated and these effects were dose-dependent. The values of total protein, SOD, CAT, and ACHE were significantly increased in the BPA group that was treated with Fagonia doses as protective or therapeutic agents than those found in the BPA group alone. In contrast, the values of MDA in the intoxicated rats that received Fagonia critica doses were significantly reduced with respect to those observed in the intoxicated control rats. These improvements were pronounced in the use of a high dose of Fagonia treatment $(5.0 \mathrm{~g} / \mathrm{kg}$. b.w.). Furthermore, better results were

Table 4 Shows the enhancement role of Fagonia cretica extract (FCE) on Bisphenol A-induced mitotic activity change in rats

\begin{tabular}{ll}
\hline Treatment & Mitotic index \\
\hline Normal control & $6.40 \pm 0.62^{\mathrm{a}}$ \\
Control oil treatment & $6.34 \pm 0.51^{\mathrm{a}}$ \\
Bisphenol A (BPA) & $3.50 \pm 0.32^{\mathrm{cd}}$ \\
Protective low dose of FCE & $3.70 \pm 0.07^{\mathrm{cd}}$ \\
Protective medium dose of FCE & $5.0 \pm 0.20^{\mathrm{b}}$ \\
Protective high dose of FCE & $6.24 \pm 0.36^{\mathrm{a}}$ \\
Therapeutic low dose of FCE & $3.1 \pm 0.28^{\mathrm{d}}$ \\
Therapeutic medium dose of FCE & $4.28 \pm 0.30^{\mathrm{bc}}$ \\
Therapeutic high dose of FCE & $5.08 \pm 0.29^{\mathrm{b}}$
\end{tabular}

All data are expressed as mean \pm SE. Means with different superscripts letters $\mathrm{a}, \mathrm{b}, \mathrm{c}, \mathrm{d}$ are significantly different at $P \leq 0.05$ observed in BPA-intoxicated rats that were treated with Fagonia doses as protective agents than those revealed in BPA-intoxicated rats that received Fagonia doses as therapeutic agents.

\section{Liver function analysis}

The results of the present experiment (Table 6) clarified a significant rise in AST, ALT, ALph, and bilirubin in BPA-intoxicated rats in comparison with untreated control. The male rat groups that received BPA and treated with FCE doses as protective or therapeutic agents had a significant decrease of the values of AST, ALT, ALph, and bilirubin as compared to BPA-intoxicated rat group alone. The amelioration of the above liver function parameters was increased by increasing the dose levels of FCE. The present findings found that the use of the highest dose $(5.0 \mathrm{~g} / \mathrm{kg}$. b.w.) of FCE as a protective or therapeutic agent gave the lowest values of AST, ALT, ALph, and bilirubin. Furthermore, the utilization of FCE as a protective agent especially by using the highest dose caused more improvements in previous parameters of liver functions and resulted in better findings than the utilization of FCE as a therapeutic agent.

\section{Kidney function analysis}

The results of the present work (Table 6) observed a significant elevation in the values of urea and creatinine in BPA-intoxicated rats as compared to those found in the control. The rat groups that exposed to BPA and gavage FCE doses as protective or therapeutic agents had a significant reduction of the values of urea and creatinine as compared to the rat group that was treated with BPA alone. 


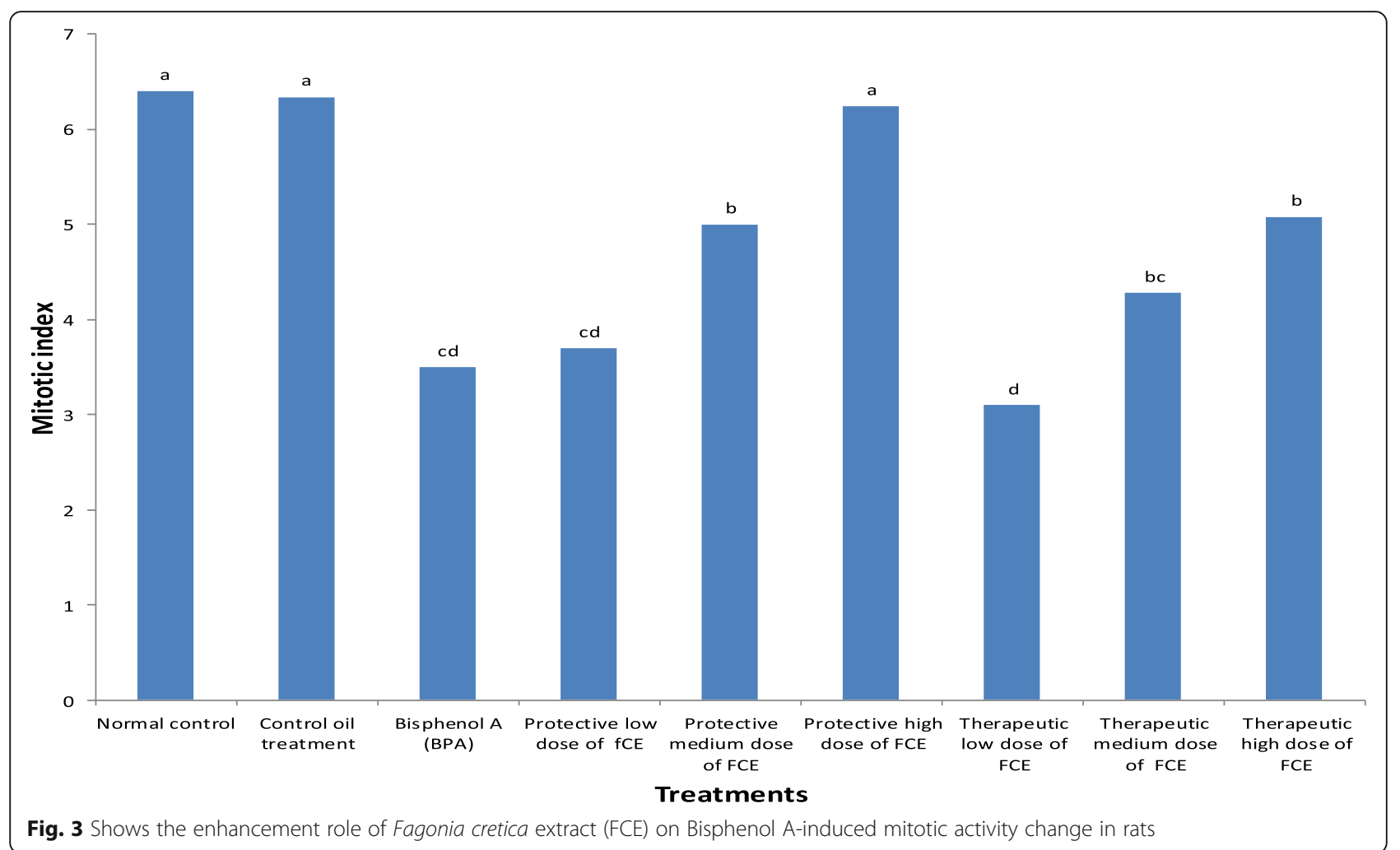

The amelioration in the above kidney function parameters in Fagonia groups increased by increasing the dose levels of FCE. Furthermore, the use of FCE as a protective agent especially by using the highest dose ameliorated more the above kidney function parameters and resulted in the best results than the use of FCE as a therapeutic agent.

The present data (Table 7) revealed significant decreases in the DNA and RNA contents in the BPAintoxicated rats as compared to those found in the control. The BPA-intoxicated rats that were treated with
FCE doses as protective or therapeutic agents had improvements of the DNA and RNA contents as compared to BPA-intoxicated rat group alone. These improvements were increased by increasing the dose level of FCE. The present findings clarified that the treatment with the high dose $(5.0 \mathrm{~g} / \mathrm{kg}$. b.w.) gave the highest values of DNA and RNA contents. Moreover, the treatment with FCE as a protective agent especially by using the highest dose improved more the genetic material contents and resulted in better results than the use of FCE as a therapeutic agent.

Table 5 Shows serum protein profile as well as endogenous lipid peroxidation and antioxidant system of serum in Bisphenol Aintoxicated rats treated with Fagonia cretica extract

\begin{tabular}{|c|c|c|c|c|c|}
\hline Treatment & Protein $\mathrm{g} / \mathrm{dl}$ & $\begin{array}{l}\mathrm{MDA} \\
\mathrm{N} \mathrm{mol} / \mathrm{ml}\end{array}$ & SOD \% (U/ml) & Catalase $(\mathrm{U} / \mathrm{ml})$ & $\begin{array}{l}\text { Acetylcholinesterase } \\
(\mathrm{U} / \mathrm{ml})\end{array}$ \\
\hline Normal control & $13.86 \pm 0.44^{\mathrm{a}}$ & $8.34 \pm 0.25^{\mathrm{e}}$ & $9.11 \pm 0.27^{a}$ & $813.25 \pm 3.27^{a}$ & $7439.63 \pm 45.31^{a}$ \\
\hline Control oil treatment & $13.98 \pm 0.45^{\mathrm{a}}$ & $8.00 \pm 0.27^{e}$ & $9.24 \pm 0.29^{a}$ & $828.78 \pm 2.23^{\mathrm{a}}$ & $7493.46 \pm 37.71^{a}$ \\
\hline Bisphenol A (BPA) & $5.82 \pm 0.31^{9}$ & $23.66 \pm 0.60^{a}$ & $2.85 \pm 0.18^{f}$ & $403.90 \pm 6.23^{9}$ & $3512.54 \pm 161.87^{9}$ \\
\hline Protective low dose of FCE & $10.22 v 0.24^{c d}$ & $12.02 \pm 0.39^{c}$ & $7.63 \pm 0.18 \mathrm{bd}$ & $684.45 \pm 6.02^{d}$ & $6208.54 \pm 47.35^{d}$ \\
\hline Protective medium dose of FCE & $10.73 \pm 0.22^{c}$ & $10.88 \pm 0.32^{d}$ & $6.94 \pm 0.10^{c}$ & $713.031 \pm 9.61^{c}$ & $6535.61 \pm 61.24^{c}$ \\
\hline Protective high dose of FCE & $11.62 \pm 0.22^{b}$ & $10.74 \pm 0.25^{d}$ & $6.13 \pm 0.15^{d}$ & $767.44 \pm 11.11^{b}$ & $6931.00 \pm 84.30^{b}$ \\
\hline Therapeutic low dose of FCE & $8.24 \pm 0.25^{f}$ & $14.50 \pm 0.21^{b}$ & $5.74 \pm 0.11^{d}$ & $600.28 \pm 3.60^{f}$ & $5845.27 \pm 60.21^{f}$ \\
\hline Therapeutic medium dose of FCE & $9.25 \pm 0.27^{e}$ & $13.82 \pm 0.28^{b}$ & $5.17 \pm 0.15^{\mathrm{e}}$ & $615.794 \pm 2.961^{f}$ & $5985.03 \pm 22.72^{\mathrm{ef}^{\mathrm{f}}}$ \\
\hline Therapeutic high dose of FCE & $9.63 \pm 0.19^{\text {de }}$ & $12.60 \pm 0.57^{c}$ & $4.66 \pm 0.12^{e}$ & $641.36 \pm 4.55^{\mathrm{e}}$ & $6117.85 \pm 2573^{\text {de }}$ \\
\hline
\end{tabular}

All data are expressed as mean \pm SE. Means with different superscripts letters $\mathrm{a}, \mathrm{b}, \mathrm{c}$ are significantly different at $P \leq 0.0$ 
Table 6 Shows liver and kidney functions of serum Bisphenol A-intoxicated rats treated with Fagonia cretica extract

\begin{tabular}{|c|c|c|c|c|c|c|}
\hline Treatment & AST (IU/I) & $\operatorname{ALT}(I \cup / I)$ & Alph (IU/I) & Bilirubin $(\mathrm{g} / \mathrm{dl})$ & Urea mg/dl & Creatinine $\mathrm{mg} / \mathrm{dl}$ \\
\hline Normal control & $47.40 \pm 0.92^{f}$ & $51.20 \pm 0.86^{9}$ & $153.91 \pm 0.79^{h}$ & $0.28 \pm 0.01^{d}$ & $22.93 \pm 0.37^{9}$ & $0.623 \pm 0.01^{d}$ \\
\hline Control oil treatment & $47.20 \pm 0.86^{f}$ & $50.80 \pm 0.86^{9}$ & $153.43 \pm 0.87^{h}$ & $0.27 \pm 0.01^{d}$ & $21.04 \pm 0.40^{9}$ & $0.625 \mathrm{v} 0.01^{d}$ \\
\hline Bisphenol A (BPA) & $81.00 \pm 1.22^{\mathrm{a}}$ & $101.40 \pm 1.72^{\mathrm{a}}$ & $415.99 \pm 5.02^{\mathrm{a}}$ & $1.33 \pm 0.1^{\mathrm{a}}$ & $54.82 \pm 0.48^{\mathrm{a}}$ & $1.27 \pm 0.06^{\mathrm{a}}$ \\
\hline Protective low dose of FCE & $52.00 \pm 0.70^{c}$ & $62.80 \pm 0.86^{c}$ & $213.06 \pm 2.17^{e}$ & $0.36 \mathrm{v} 0.01^{\mathrm{bcd}}$ & $28.96 \pm 0.38^{d}$ & $0.719 \pm 0.01^{b c}$ \\
\hline Protective medium dose of FCE & $58.20 \pm 1.39^{9}$ & $61.00 \pm 0.70^{\mathrm{ef}}$ & $199.43 \pm 1.79^{f}$ & $0.34 \pm 0.01^{c d}$ & $27.52 \pm 0.28^{e}$ & $0.719 \pm 0.17^{b c}$ \\
\hline Protective high dose of FCE & $55.00 \pm 0.70^{c}$ & $58.60 \pm 0.51^{f}$ & $187.37 \pm 1.18^{9}$ & $0.31 \pm 0.01^{c d}$ & $25.63 \pm 0.50^{f}$ & $0.68 \pm 0.005^{c d}$ \\
\hline Therapeutic low dose of FCE & $69.00 \pm 0.70^{b}$ & $73.80 \pm 0.58^{\mathrm{b}}$ & $243.87 \pm 4.72^{b}$ & $0.45 \pm 0.14^{b}$ & $34.11 \pm 0.35^{b}$ & $0.783 \pm 0.01^{b}$ \\
\hline Therapeutic medium dose of FCE & $68.00 \pm 0.94^{b}$ & $70.60 \pm 0.51^{c}$ & $234.27 \pm 2.40^{c}$ & $0.41 \pm 0.01^{b c}$ & $31.90 \pm 0.50^{c}$ & $0.758 \pm 0.01^{b c}$ \\
\hline Therapeutic high dose of FCE & $64.00 \pm 0.70^{c}$ & $67.20 \pm 0.86^{d}$ & $223.23 \pm 1.93^{d}$ & $0.39 \pm 0.01^{b c}$ & $30.88 \pm 0.39^{c}$ & $0.737 \pm 0.01^{b c}$ \\
\hline
\end{tabular}

All data are expressed as mean \pm SE. Means with different superscripts letters $\mathrm{a}, \mathrm{b}, \mathrm{c}$ are significantly different at $P \leq 0.05$

\section{Discussion \\ Genetic study \\ The effect of BPA on genetic changes}

DNA damage In the present work, the comet assay analysis showed that the treatment with BPA had induced an elevation in DNA strand breaks causing greater DNA migration out of the nucleus into the tail of the comet in the hepatic tissue. This massive DNA damage was observed to be significantly increased in rats exposed to BPA in relation to those of normal control. These findings were found to be in agreement with the report of Eid et al. (2015) who observed by using comet assay method a significant elevation of DNA damage in hepatic tissue of rats received BPA as compared to those found in the normal control. Also, similarly in the previous study, Parry et al. (2002) demonstrated DNA damage in human cell line (MCF) after BPA exposure with respect to untreated MCF cells. Mourad and Khadrawy (2012) detected massive DNA damage in cell line from hamster ovary $(\mathrm{CHOKI})$ that was treated with BPA relative to those observed in normal control.
Cytogenetic alterations The obtained data in the present study revealed that the exposure to BPA treatment had induced significant increases in cytogenetic alterations that involved micronuclei, chromosome anomalies, and mitotic activity changes with respect to normal control as follows:

\section{- Chromosome aberrations}

Concerning the inducing of chromosome aberrations, the present findings were similar to that reported of Aghajanpour-Mir (2016) who illustrated massive chromosome damage in MCF-7 cell line that exposed to BPA in comparison with that found in the normal control. These chromosome anomalies included structural and numerical aberrations. Structural aberrations involved chromosomal gaps and breaks, chromatid gaps and breaks, fragments, ring chromosomes, and chromosome rearrangements such as triradials. Chromosome aneuploidies were the most frequent numerical aberrations. Also, previous several studies by Pfeiffer et al. (1997), Tsutsui et al. (1998), Ochi (1999) and Tsutsui et al. (2000) demonstrated DNA adduct

Table 7 Shows the nucleic acid (DNA and RNA) contents in Bisphenol A-intoxicated rats treated with Fagonia cretica extract

\begin{tabular}{|c|c|c|c|c|c|c|}
\hline \multirow[t]{2}{*}{ Treatment } & \multicolumn{3}{|c|}{ DNA content in tissues of } & \multicolumn{3}{|c|}{ RNA content in tissues of } \\
\hline & Liver & Kidney & Brain & Liver & Kidney & Brain \\
\hline Normal control & $0.66 \pm 0.01^{a}$ & $0.47 \pm 0.02^{a}$ & $0.51 \pm 0.00^{a}$ & $0.41 \pm 0.0^{\mathrm{a}}$ & $0.31 \pm 0.0^{\mathrm{a}}$ & $0.35 \pm 0.0^{\mathrm{a}}$ \\
\hline Control oil treatment & $0.67 \pm 0.01^{\mathrm{a}}$ & $0.46 \pm 0.01^{\mathrm{a}}$ & $0.51 \pm 0.01^{\mathrm{a}}$ & $0.41 \pm 0.01^{a}$ & $0.32 \pm 0.01^{\mathrm{a}}$ & $0.36 \pm 0.0^{\mathrm{a}}$ \\
\hline Bisphenol A (BPA) & $0.28 \pm 0.00^{f}$ & $0.21 \pm 0.01^{g}$ & $0.23 \pm 0.01^{9}$ & $0.22 \pm 0.0^{9}$ & $0.16 \pm 0.01^{f}$ & $0.15 \pm 0.01^{f}$ \\
\hline Protective low dose of FCE & $0.50 \pm 0.01^{c}$ & $0.39 \pm 0.01^{c d}$ & $0.40 \pm 0.00^{c}$ & $0.32 \pm 0.0^{d}$ & $0.26 \pm 0.01^{c}$ & $0.25 \pm 0.0^{c}$ \\
\hline Protective medium dose of FCE & $0.56 \pm 0.00^{b}$ & $0.40 \pm 0.01^{b c}$ & $0.46 \pm 0.01^{b}$ & $0.35 \pm 0.0^{c}$ & $0.27 \pm 0.0^{b}$ & $0.28 \pm 0.0^{b}$ \\
\hline Protective high dose of FCE & $0.59 \pm 0.01^{b}$ & $0.42 \pm 0.01^{b}$ & $0.48 \pm 0.01^{b}$ & $0.38 \pm 0.0^{b}$ & $0.29 \pm 0.01^{b}$ & $0.29 \pm 0.0^{b}$ \\
\hline Therapeutic low dose of FCE & $0.41 \pm 0.00^{\mathrm{e}}$ & $0.33 \pm 0.0^{f}$ & $0.32 \pm 0.0^{f}$ & $0.27 \pm 0.0^{f}$ & $0.20 \pm 0.0^{e}$ & $0.20 \mathrm{v} 0.01^{\mathrm{e}}$ \\
\hline Therapeutic medium dose of FCE & $0.44 \pm 0.00^{d}$ & $0.35 \pm 0.0^{\mathrm{ef}}$ & $0.35 \pm 0.0^{c}$ & $0.28 \pm 0.0^{\text {ef }}$ & $0.21 \pm 0.0^{\mathrm{e}}$ & $0.22 \pm 0.1^{c d}$ \\
\hline Therapeutic high dose of FCE & $0.47 \pm 0.00^{d}$ & $0.37 \pm 0.01^{\mathrm{de}}$ & $0.38 \pm 0.0^{d}$ & $0.30 \pm 0.0^{\mathrm{e}}$ & $0.23 \pm 0.01^{d}$ & $0.23 \pm 0.0^{c d}$ \\
\hline
\end{tabular}

All data are expressed as mean \pm SE. Means with different superscripts letters $\mathrm{a}, \mathrm{b}, \mathrm{c}$ are significantly different at $P \leq 0.05$ 
formation and chromosome anomalies in different somatic mammalian cells that were treated with BPA as compared to normal control. Moreover, Machtinger et al. (2013); Liu et al. (2013) and Fic et al. (2013) observed that BPA treatment could induce numerical chromosome anomalies such as aneuploidy through disruption of meiotic or mitotic process and also genomic structural aberrations such as DNA breakage. Allard and Colaiacovo (2010) clarified that BPA impairs the double-strand break repair machinery causing chromosome aberrations. Also, the same authors (Allard and Colaiacovo, 2010) reported that BPA exposure resulted in downregulation of double-strand break repair (DSBR) genes in both somatic and germinal cells, thereby induce impairing maintenance of genomic integrity during meiosis and mitosis divisions. Furthermore, synaptic defects could be induced due to the BPA treatment causing chromosome anomalies (Susiarjo et al., 2007; Aghajanpour-Mir, 2016).

\section{- Micronuclei and mitotic changes}

Concerning the inducing micronuclei and mitotic activity changes in the current work, the toxic effects of BPA that induced such abnormalities had not been previously reported in vivo of the mammalian cells in the literature. However, Aghajanpour-Mir et al., (2016) reported invitro study that the direct genotoxic effects due to BPA treatment included the inducing of micronuclei (MNPEC) and mitotic activity changes in MCF-7 cell line.

In the present study, the inducing DNA damage and cytogenetic changes due to BPA treatment might be due to that BPA during its metabolites in liver produce reactive oxygen species (ROS) and nitric oxide (NO) ( Chitra et al., 2003; Asahi et al., 2010; Moon et al., 2012; Eid et al., 2015). These constituents (ROS and NO) were found to be strong oxidants that are capable of attacking and modifying lipids, proteins, and DNA as well as depleting antioxidant defenses inducing genotoxic effects that include DNA damage and cytogenetic changes in mammalian cells (Moon et al., 2012; Eid et al., 2015).

Also, Bauer (2000), Kabuto et al. (2003), and Eid et al. (2015) demonstrated that BPA treatment had induced lowering in the antioxidant enzyme activities (SOD, CAT, GPx) and increase in levels of ROS and NO and consequently lead to genotoxic effect in different mammalian tissues. Also, in the previous study, Grattagliano et al. (1999) clarified that NO is considered to be highly diffusible free radicals. This component can react with superoxide $(\mathrm{O} 2)$ leading to the formation of peroxynitrite (ONOO) which is a highly reactive free radical resulting in more harmful effects on the mammalian tissues such as nitrosative stress and consequently induce genotoxic effects.

\section{Effect of using FCE on genetic changes}

In the current study, the results exhibited that the utilization of FCE as a protective or therapeutic agent could minimize and inhibit the genotoxic effects induced by BPA in rat tissues. The occurring of tail lengths of DNA comets, inducing of micronuclei, chromosome aberration frequencies, and mitotic activity changes were significantly diminished compared with BPA treatment alone. Best results were obtained by utilizing FCE as a protective agent than its use as a therapeutic agent. So, the present findings proved that this natural product (FCE) has potent effects on the maintenance of the genetic materials against BPA genotoxicity. In spite of the literature investigated, the extensive traditional utilize of Fagonia cretica, its antigenotoxicity profile in mammalian cells remains not obvious. However, several studies recorded that FCE was found to have significant anticancer and antitumor activity (Saeed, 1969; Hussain et al., 2007), anti-inflammatory, and wound healing property (Saleh et al., 2011). Moreover, Rawal et al. (2004) found that Fagonia cretica L. extract was effective in enhancing the GSH levels, improving gene expression of gammaglutamylcysteine ligase and $\mathrm{Cu}-\mathrm{ZnSOD}$ genes against oxidative stress in rats.

Furthermore, the use of extract of such medicinal plant was found to be significantly minimized the expression of iNOS gene which plays a main role in neuronal injury during hypoxia-ischemia (Rawal et al., 2004; Puri and Bhandari, 2014). Also, in rats, Rawal et al. (2004) observed potent free radical scavenging properties of FCE against reactive oxygen and nitrogen species that studied by electron paramagnetic resonance spectroscopy. Lam et al. (2012) revealed that FCE could cause cell cycle arrest and apoptosis via $\mathrm{P}^{53}$-dependent and independent mechanisms, with activation of the DNA damage response. Also, their results clarified that FCE contains anticancer factors that act singly or in combination against the proliferation of breast cancer cells via DNA damage-induced FOXO3a and $\mathrm{P}^{53}$ expression.

\section{Biochemical study Liver and kidney functions of serum Bisphenol A-intoxicated rats}

In the present work, the biochemical data observed significant biochemical alterations in liver and kidney functions in rats exposed to BPA. The activities on the levels of ALT, AST, ALP, and bilirubin in the serum were shown to be very great elevation, as compared to those found in the control. These harmful effects in such biochemical parameter indicator of acute hepatic necrosis and hepatobiliary disease, as well as the elevation of AST and ALT levels, indicate initial hepatocellular damage (Michalowicz and Duda, 2007; Darwish et al., 2011). 
Several studies reported in different mammalian cells that exposure to BPA led to an increase of oxidative stress causing inhibition of mitochondria and microsome functions in the liver, also hydroxylated metabolites are induced and consequently, excess of reactive oxygen species $\left(\mathrm{ROS}_{\mathrm{s}}\right)$ are formed. These $\mathrm{ROS}_{\mathrm{s}}$ attack biological compounds in the living cells such as lipid, protein, nucleic acids, and other compounds (Pigeolet et al., 1990; Eid et al., 2015; Poormoosavi et al.; 2018; Shirani et al., 2019) leading to adverse effect on the parameters of ALT, AST, ALP, and bilirubin.

The results of the present experiment on rats revealed that the treatment with BPA resulted in a significant increase in serum uric acid and creatinine. These findings suggest that BPA treatment induce deleterious changes in kidney cells. These adverse effects are indicators of the occurring of impairments of kidney functions (Ye et al., 2008, Ahmed et al., 2015). Similarly, Calafat et al. (2005) and Ye et al. (2008) observed in humans that the exposure to BPA led to an increase of urea level than the normal level in $90 \%$ of the population worldwide. Also, Ahmed et al. (2015) reported in adult male rats that the treatment with BPA had induced adverse effect on kidney tissues causing an increase levels of urea and creatinine as compared to the untreated group. Shirani et al. (2019) demonstrated in the recent study that the kidney weight in the male rats that received BPA significantly decreased as compared to those found in the control.

\section{Lipid peroxidation(MDA) and antioxidant system of serum in Bisphenol A-intoxicated rats}

From the present results, it was seen that activates of SOD, CAT, and ACHE were significantly reduced under the exposure to BPA with respect to normal control. In contrast, the level of MDA in BPA-intoxicated rats was significantly elevated in comparison with those found in untreated rats (control group). These findings are in agreement with that reported in different mammalian cells by Pigeolet et al. (1990); Eid et al. (2015) and Poormoosavi et al. (2018) who observed that the exposure to BPA led to reduction in the antioxidant enzyme activities and increase of MDA level. Also, in studies on rats by Bindhoumol et al. (2003); Hassan et al. (2012 b) and Kourouma et al. (2014); Kamel et al. (2018); AbdelRahman et al. (2018) and Ozaydin et al. (2018), the obtained results revealed that the treatment with BPA led to increase of percentages of MDA and decrease of values of SOD, CAT, and ACHE. These studies suggested that the major biochemical influence of BPA is the formation of oxidation systems resulting in hydroxylated metabolites. These hydroxylated metabolites with ROS radicals can cause deterioration in the different metabolic pathways in living cells in which the level of
MDA is increased, but the activities of SOD, CAT, and ACHE are decreased.

\section{Nucleic acid (DNA and RNA) contents and serum protein profile}

The present data on rats showed that exposure to BPA led to a significant reduction in the nucleic acid contents. Some studies by Sangai and Verm (2011) and Abdel-Rahman et al, (2018) suggested that during the metabolic processes for BPA in the liver, the intracellular $\mathrm{ROS}_{\mathrm{s}}$ are formed. These reactive oxygen species involved superoxide anion $\left(\mathrm{O}^{-}\right)$, hydroxyl radical $(-\mathrm{OH})$ and hydrogen peroxide $\left(\mathrm{H}_{2} \mathrm{O}_{2}\right)$. These constituents of radicals interact with cell components such as nucleic acids (DNA and RNA), protein, and lipids inducing a reduction of nucleic acids and protein contents in living cells. Also, Atkinson and Roy (1995) and Collins and Harrington (2002) reported that the reduction of DNA, RNA, and protein contents by exposure to BPA might be due to the formation of DNA adducts as a result of interaction between $\mathrm{ROS}_{\mathrm{s}}$ and DNA structure. These adducts inhibit the transcription processes and can prevent the formation of mRNA leading to inhibition of protein synthesis. Also, our findings are in agreement with those observed by Sangai and Verma (2011) who observed that the treatment with BPA in mice induced a significant decrease in DNA, RNA, and protein contents in liver and kidney tissues relative to untreated mice (control group).

Moreover, Shirani et al., (2019) reported that the exposure to BPA caused an excess of ROS and MDA leading to DNA damage in different tissues in the mammalian organs including the brain organ.

Abdel-Rahman et al. (2018) revealed that the elevation of the percentage of MDA in rats due to the treatment with BPA induced increase in comet tail DNA\%.

\section{Effect of FCE utilization on biochemical alteration}

In the present study, it was found that the BPAintoxicated rats that received different doses of FCE as protective or therapeutic agents had enhancement in liver and kidney functions than intoxicated control rats. This study showed better results that were seen by utilizing FCE as a protective agent than its use as a therapeutic agent. FCE attenuates the oxidative stress and enhances the levels of activity of antioxidative enzymes such as SOD, CAT, and ACHE. Moreover, it improved the nucleic acids (DNA and RNA) and protein contents in the liver, kidney, and brain tissues. In contrast, FCE treatment induced inhibition of the extent of lipid peroxidation (MDA) and reduced the values of ALT, AST, ALP, and bilirubin as well as it minimized the percentages of urea and creatinine. The present ameliorations of FCE treatment on mentioned biochemical parameters 
might be owing to its containing high percentages of natural antioxidants which have important properties as processes of antioxidation and antigenotoxicity (Alam, 2011; Samreen et al., 2014; Salah Eldin et al., 2015; Azam et al., 2018). These processes of antitoxicity caused suppression of the extent of lipid peroxidation (MDA), stimulated the hydroxyl radical scavenging activity, and prevented the formation of DNA adduct (Lam et al., 2012; Salah Eldin et al., 2015; Azam et al., 2018). Moreover, the treatment with FCE was used to cure each of kidney injury (Kamran et al., 2017) and hepatic ailments (Azam et al., 2018). Also, FCE exhibited antimicrobial activity (Sajid et al., 2011), antibreast cancer (Matthew, 2012), antitumor (Alam, 2011) and hemorrhagic inhibitor (Razi et al., 2011).

\section{Conclusion}

These findings clarified a new insight into the protective effect of FCE in minimizing BPA-induced genotoxicity and biochemical changes in rats detecting the capability of such medicinal plant for alleviating the adverse effect of BPA.

\section{Abbreviations}

ACHE: Acetylcholinesterase; ALPh: Alkaline phosphate; ALT: Alanine transaminase; AST: Aspartate transaminase; BPA: Bisphenol A; CAT: Catalase; FCE: Fagonia cretica extract; MDA: Malondialdehyde; MNPCE: Micronucleated polychromatic erythrocytes; PCEs: Polychromatic erythrocytes;

SOD: Superoxide dismutase

\section{Acknowledgement}

The authors thank Engineer Fayd-Alla Mostafa Fayd-Alla who collected the Fagonia cretica plant from Burg El Arab desert region, Egypt. This plant has been identified in the Department of Horticultural Crops Technology, National Research Centre, Dokki, Cairo, Egypt.

\section{Authors' contributions}

All the authors have accepted responsibility for the entire content of this submitted manuscript and approved submission.

\section{Funding}

This research did not receive any specific grant from funding agencies in the public, commercial, or not-for-profit sectors.

\section{Availability of data and materials}

All data generated or analyzed during this study are included within the article.

\section{Ethics approval and consent to participate}

Authors declare that the work is ethically approved and consent to participate.

\section{Consent for publication}

Authors declare that the work has consented for publication.

\section{Competing interests}

The authors declare that they have no competing interests.

\section{Author details}

${ }^{1}$ Departments of Cell Biology, National Research Centre, Dokki, Cairo, Egypt. ${ }^{2}$ Horticultural Crops Technology, National Research Centre, Dokki, Cairo, Egypt.
Received: 26 August 2019 Accepted: 27 February 2020

Published online: 04 May 2020

\section{References}

Abdel-Rahman HG, Abdelrazek HMA, Zeidan DW, Mohamed RM, Abdelazim AM (2018) Lycopene: Hepatoprotictive and antioxidant effect toward Bisphenol A induced toxicity in female waster rat. Oxidative Medicine Cellular Longevity. 2018

Aebi H. A catalase in vitro" in "methods Enzymal. 1984; 105:121-126.

Aghajanpour-Mir SM, Zabihi E, Akhavan-Niaki H, Keyhani E, Bagherizadeh I, Biglari S, Behjati $F$ (2016) The genotoxic and cytotoxic effects of Bisphenol-A (BPA) in MCF-7 cell line and amniocytes. Int J Mol Cell Med Winter. 5(1):19-29

Ahmed W, Moselhy W, Nabil T (2015) Bisphenol A toxicity in adult male rats: hematological, biochemical and histopathological approach. Glob Vet. 14(2): 228-238

Alam EA (2011) Morphological, phytochemical and biological screening on three Egyptian species of Fagonia. Acad Arend. 3:18-27

Allard P, Colaiacovo MP (2010) Bisphenol A impairs the doublestrand break repair machinery in the germline and causes chromosome abnormalities. Proc Natl Acad Sci U S A. 107:20405-20410

Asahi J, Kamo H, Baba R, Doi Y, Yamashita A (2010) Bisphenol A induces endoplasmic reticulum stress-associated apoptosis in mouse nonparenchymal hepatocytes. Life Sci. 87:431-438

Atkinson A, Roy D (1995) In vitro conversion environmental estrogenic chemical bisphenol A to DNA binding metabolites Biochem. Biophys. Res Commum. 210:424-433

Azam F, Sheikh N, Ali G, Tayyeb A (2018) Fagonia indica repairs hepatic damage through expression regulation of toll-like receptors in a liver injury model. J Immunol Res 2018:12 pages

Bartles H, Bohmer M (1972) Colorimrtric kinetic method to determined creatinine in serum or plasma. Clin Chem Acta. 37:193-198

Bauer G (2000) Reactive oxygen and nitrogen species: efficient, selective, and interactive signals during intercellular induction of apoptosis. Anticancer Res. 20:4115-4139

Ben-Jonathan N, Hugo ER, Brandebourg TD (2009) Effects of bisphenol A on adipokine release from human adipose tissue: implications for the metabolic syndrome. Mol. Cell. Endocrinol. 304:49-54

Bindhoumol V, Chitra KC, Mathur PP (2003) Biophenal A induces reactive oxygen species generation in liver of male rats. Toxicology. 188(2-3):117-124

Blasiak J, Arabski M, Krupa R, Wozniak K, Zadrozny M, Kasznikeki J, Zurawska M, Drzewoski J (2004) DNA damage and repair in type 2 diabetes mellitus. Mutation Res. 554(1-2):297-304

Calafat-AM KZ, Reidy IA, Caudill SP, Ekong J, Needham LL (2005) Urinary Concentration of bisphenol $\mathrm{A}$ and 4-nonylphenol in a human reference population. Environ Health Perspect 113:391-395

Cao XL, Zhang J, Goodyer CG, Hayward S, Cooke GM (2012) Bisphenol A in human placental and fetal liver tissues collected from greater Montreal area (Quebec) during (1998- 2008). Chemosphere. 89:505-511

Chitra KC, Rao KR, Mathur PP (2003) Effect of bisphenol A and co-administration of bisphenol $A$ and vitamin $C$ on epididymis of adult rats: a histological and biochemical study. Asian J Androl. 5:203-208

Collins A, Dusinska M, Franklin SM, Petrovska H, Duthie S, Fillion T, Panayiotidis M, Raslova K, Vaughan N (1997) Comet assay in human biomonitoring studies: Reliability, validation, and applications. Environ Mol Mutation. 30:139-146

Collins A, Harrington V (2002) Repair of oxidative DNA damage, assessing its contribution to cancer prevention. Mutagenesis. 17:489-493

Darwish HR, Omara EA, Abdel-Aziz KB, Farag IM, Nada AA, Tawfek NS (2011) Saccharomyces cerevisiae modultes aflatoxin-induced toxicity in male albino mice. Repot and Opinion. 3:42-43

Eid JI, Eissa SM, EL Ghor AA (2015) Bisphenol A induced oxidative stress and DNA damage in hepatic tissue of female rat offspring. J Basic App Zoology. 7:1019

Fawcett JK, Scott JE. Urease-Berthelot method to determined urea Concentration in serum or plasma I chem Path. 1960; 13: 156-159.

Fic A, Zegura B, Sollner Dolenc M et al (2013) Mutagenicity and DNA damage of bisphenol A and its structural analogues in HepG2 cells. Arh Hig Rada Toksikol. 64:3-14

Grattagliano I, Vendemiale G, Lauterburg BH (1999) Reperfusion injury of the liver: role of mitochondria and protection by glutathione ester. J Surg Res. 86:2-8

Haighton L, Card JW, Lynch B et al (2012) Bisphenol A and infant neonatal neurobehavior. Environ Health Perspect. 120:A102 
Hassan ZK, Elobeid MA, Virk P (2012 b) Bisphenol A induced hepatotoxicity through oxidative stress in rat model. Oxid Med Cell Ponger. 2012:1-6

Henry RJ. Clinical chemistry: In "principles and Techics" Harpar and Row publishers $2^{\text {nd }}$ Edition. 1974; PP917-927.

Hunt PA, Koehler KE, Susiarjo M, Hodges CA, Lagan A, Voigt RC, Thomas S, Thomas BF, Hassold TJ (2003) Bisphenol A exposure causes meiotic aneuploidy in the female mouse. Current Biology. 13:546-553

Hussain A, Zia M, Mirza B (2007) Cytotoxic and antitumor potential of Fagonia cretica L. Turk J Biol. 31:19-24

IAEC (Institutional Animal Ethics Committee. Commit for the purpose of control, supervision of experiments on animals (CPCSEA) CPCSEA is guidelines for laboratory animal facility. 2010.

Ikezuki Y, Tsutsumi O, Takai Y, Kamei Y, Taketani Y (2002) Determination of Bisphenol A concentrations in human biological fluids reveals significant early prenatal exposure. Hum Reprod. 17:2839-2841

Kabuto H, Hasuike S, Minagawa N, Shishibori T (2003) Effects of bisphenol A on the metabolisms of active oxygen species in mouse tissues. Environ Res. 93 31-35

Kamel AH, Fouad MA, Moussa HM (2018) The adverse effects of bisphenol A on male albino rats. J BasicApp Zoology. 79(6):1-9

Kamran SH, Shoaib RM, Ahmad M, Ishtiaq S, Anwar R (2017) Antidiabetic and renoprotictive effect of Fagonia Cretica L. methanolic extract and citrus paradise Macfadi juice in alloxan induced diabetic rabbits. J Pharm Pharmcognoy Res. 5(6):365-380

Kourouma A, Peng D, Chao Q, Yaima M, Lopez T, Lix Changjiang L, Chengmin W, Wenjuan F, Sygin Q, ZYu TingKing Y, Kedi Y (2014) Bisphenol A induced reactive oxygen species (ROS) in the liver and epididymal semen quality in adult sprage Dawley Rats. J Toxicol Environ Health Sci 6(4):103-112

Krishna G, Hayashi M (2000) In vivo rodent micronucleus assay: protocol, conduct and data interpretation. Mutation Research. 455(1-2):155-166

Lam M, Carmichael AR, Griffiths HR. An aqueous extract of Fagonia cretica induces DNA damage, cell cycle arrest and apoptosis in breast cancer cells via $\mathrm{FoxO}_{3 \mathrm{a}}$ and p53 expression. Plosone. 2012; 7(6).

Liu C, Duan W, Li R et al (2013) Exposure to bisphenol A disrupts meiotic progression during spermatogenesis in adult rats through estrogen-like activity. Cell Death Dis. 4:e676

Machtinger R, Combelles CM, Missmer SA et al (2013) Bisphenol-A and human oocyte maturation in vitro. Hum Reprod. 28:2735-2745

Matthew L. Cytotoxic activity of fagonia cretica against human breast cancer cells. Ph.D thesis, Aston University. Uk. 2012.

Michalowicz J, Duda W (2007) Phenols-Sources and Toxicity. A Rev Polish J of Environ Stud. 16:347-362

Mirmira P, Evans-Molina C (2014) Bisphenol A, obesity, and type 2 diabetes mellitus: genuine concern or unnecessary preoccupation? Transl Res. 164:1321

Mourad IM, Khadrawy YA (2012) The sensitivity of liver, kidney and testis of rats to oxidative stress induced by different doses of Bisphenol A. Int J life Sci pharma Res. 2:419-428

Moon MK, Kim MJ, Jung IK, Koo YD, Ann HY, Lee KJ, Kim SH, Yoon YC, Cho BJ, Park KS, Jang HC, Park YJ (2012) Bisphenol A Impairs Mitochondrial Function in the Liver at Doses below the No Observed Adverse Effect Level. J Korean Med Sci. 27 (6):644

National Toxicology Program (1985) Carcinogenesis Bioassay of Bisphenol A (CAS No. 80-05-7) in F344 Rats and B6C3F1 Mice (Feed Study). Tech Rep Ser 215: $1-116$

National Toxicology Program. NTP-CERHR monograph on the potential human reproductive and developmental effects of Bisphenol A. NTP CERHR MON 22: i-III1. 2008.

Nishikimi M, Roa NA, Yogi K (1972) Measurment of superoxide dismutase. Biophys Res Cmmon. 46:849-854

Ochi T (1999) Induction of multiple microtubule-organizing centers, multipolar spindles and multipolar division in cultured V79 cells exposed to diethylstilbestrol, estradiol-17beta and bisphenol A. Mutat Res. 431:105-121

Ohkama H, Ohishi W, Yag K (1979) Colormetric method for research only. Anal Boichem. 95:351-356

Ozaydin T, Oznurlu Y, Sur E, Celik L, Uluisik D, Dayan MO (2018) Effect of bisphenol $\mathrm{A}$ on antioxidant system and lipid profile in rats. Biotech Histochem. 93(4):231-238

Parry EM, Parry JM, Corso C, Doherty A, Haddad F et al (2002) Detection and characterization of mechanisms of action of aneugenic chemicals. Mutagenesis. 17:509-521
Pearse AGE (1985) Histochemistry theoretical applied volume tow: analytical technology, churcholl Livingston. Fourth edition, Edinburgh London Melbourne and New York

Pfeiffer E, Rosenberg B, Deuschel S, Metzler M (1997) Interference with microtubules and induction of micronuclei in vitro by various bisphenols. Mutat Res. 390:21-31

Pigeolet E, Corbisier P, Houbion A, Lambert D, Michiels OC, Racs M, Zachary D, Ramacle J (1990) Glutathione peroxidase, superoxide dismutase and Catalase inactivation by peroxides and oxygen derived free radicals. Mech Ageing Dev. 51:283-290

Poormoosavi SM, Najafzadehvarzi H, Behmanesh MA, Amirgholami R (2018) Protective effects of Asparagus officinalis extract against Bisphenol Ainduced toxicity in Wistar rats. Toxicol Rep. 5:427-433

Preston RJ, Dean BJ, Galloway AF, Holden H, Mcfee S, Shelby M (1987; Oct) Mammalian in vivo cytogenetic assays. Analysis of chromosome aberrations in bone marrow cells. Mutant Research 189(2):157-165

Puri D, Bhandari A. Fagonia: a potential medicinal desert plant . Journal of NPA. 2014; XXVII (1): 28-33.

Rawal AK, Muddeshwar MG, Biswas SK (2004) Rubia, cordifolia, Fagonia cretica L and Tinospora cordifolia exert neuroprotection by modulating the antioxidant system in rat hippocampal slices subjected to oxygen glucose deprivation. BMC Complementary and Alternative Medicine 4:11

Razi MT ,Hassan Bin Asad MH ,Taous Khan,Chaudhary MZ, Ansari MT, Arshad MA, Saqib QN. Antihaemorrhagic potentials of Fagonia cretica against Naja naja karachiensis (black Pakistan cobra) venom. Natural Product Research 2011; 25 (20): 1902-1907.

Saeed MA (1969) Hamdard Pharmacopoeia of eastern medicine. Hamdard Pharmacopoeia 1

Sajid B, Alia E, Rizwana K, Uzma S, Alamgeer HM (2011) Phytochemical screening and antimicrobial activity of Fagonia cretica plant extracts against selected microbes. J Pharma Res 4(4):962-963

Salah Eldin H, Abdal Gadir H, Hassan A (2015) Evaluation of the hepatoprotective activity of Fagonia cretica. JPRPC. 3:1-6

Samreen Saleem, Laila Jafri, Jasia Bokari, Nazrf Vllah, Bushra Mirza. Fagonia cretica L: Antioxidant potential, protective effection $\mathrm{H}_{2} \mathrm{O}_{2}$ - induced DNA damage and identification polyphenol by RP- HPLC analysis. Not Prod Chem Res. 2014; (2) 2:5.

Saleh IA, Hasan SY, Aftab A (2011) Anti-inflammantory and wound healing activity of Fagonia schweinfurthi alcoholic extract herbal gel on albino rats. African J Pharma Pharmacol 5(17):19966-12001

Sangai NP, Verma RJ (2011) Quercetin alleviates bisphenol A induced changes in nucleic acid and protein contents in mice. Acta eoloniae Pharmaceutica Drug Research. 68(6):867-873

Scandinavien Socrety for clmical chemistary and clinical physicology (1974) Recommended method for determination of enzymes in blood. Scand J clin lob Invest 33:291-298

Schonfelder G (2002) WittfohtW, Hopp H, Talsness CE, Paul M, et al. Parent bisphenol A accumulation in the human maternal-fetalplacental unit. Environ Health Perspect. 110:A703-A770

Shalaby AFZ. Ecological and sociological conditions under which certain medicinal plants of the Egyptian desert live. M.Sc. Thesis, Fac. Sc., Cairo Univ. 1958.

Sharkawy MH. Ecological and Sociological studies on the plant communities of the Fuka-Ras El Hikma area, western desert of Egypt, M.Sc. Thesis, Fac. Sc., Alex. Univ. 1961

Shirani M, Alizadeh S, Mahdavinia M, Dehghane MA. The ameliorative effect of quercetin on bisphenol A-induced toxicity in mitochondria Bolated from rats. Environmental Science and Pollution Research. 2019.

Shubber EK, Juma AS (1999) Cytogenetic effects of plants extract of Urtica dioca on mouse somatic cells. The Nucleus. 42(3):182-187

Steven CK. Alamme and Aspartat aminotransforrase principle and usage in liver function, in clinical chemistry theory, analysis and coordination Janes I. Tjenifer R.eds. M.Mos by, London $3^{\text {rd }}$ ed. 1996; 504- 527.

Strong AL, Miller DFB, Buechlein AM, Fang F, Glowacki J, McLachlan JA, Nephew KP, Burow ME, Bunnell BA (2016) Bisphenol A alters the selfrenewal and differentiation capacity of human bone-marrow derived mesenchymal stem cells. Endocrine Disruptors. https://doi.org/10.1080/ 23273747.2016.1200344

Sun Y, Irie M, Kishikawa N, Wada M, Kuroda N et al (2004) Determination of bisphenol A in human breast milk by HPLC with column-switching and fluorescence detection. Biomed Chromatogr. 18:501-507 
Susiarjo M, Hassold TJ, Freeman E et al (2007) Bisphenol A exposure in utero disrupts early oogenesis in the mouse. PLoS genetics. 3:e5

Tsutsui T, Tamura Y, Suzuki A, Hirose Y, Kobayashi M, Nishimura H, Metzler M, Barrett JC (2000) Mammalian cell transformation and aneuploidy induced by five bisphenols. Int J Cancer. 86:151-154

Tsutsui T, Tamura Y, Yagi E, Hasegawa K, Takahashi M, Maizumi N, Yamaguchi F, Barrett JC (1998) Bisphenol A induces cellular transformation, aneuploidy and DNA adduct formation in cultured Syrian hamster embryo cells. Int J Cancer. 75:290-294

Vandenberg IN, Hauser R, Marcus M, Olea N, Welshons WV (2007) Human exposure to bisphenol A (BPA). Report Toxico. 24:139-177

Wan Y, Choi K, Kim S, Ji K, Chang H, Wiseman S, Jones PD, Khim JS, Park S, Park J, Lam MH, Giesy JP (2010) Hydroxylated polybrominated diphenyl ethers and bisphenol A in pregnant women and their matching fetuses: placental transfer and potential risks. Environ Sci Technol. 44:5233-5239

Walter M, Gerade H (1970) Coloimetre method for resear chanly. Microchem J. 15:231-241

Xia W, Jiang Y, Li Y, Wan Y, Liu J, et al. Early-life exposure to bisphenol A induces liver injury in rats involvement of mitochondria-mediated apoptosis. 2014; PLoS One 9

Ye X, Pierik FH, Hauser R, Outy S, Angeres, J, Park MM, Burdor FA, HoFaam A, Jaddoe WW, Mackenboch JP, Steegers EAP, Tiemeier H, Longnecker MP. Urinary metabolite concentration of organophosphorus pesticides, bisphenol $\mathrm{A}$ and phthalates among pregnant women in Rolter dam, the Netherlands, the Generation R study. Environ. Res. 2008; 108:260-267.

\section{Publisher's Note}

Springer Nature remains neutral with regard to jurisdictional claims in published maps and institutional affiliations.

\section{Submit your manuscript to a SpringerOpen ${ }^{\circ}$ journal and benefit from:}

- Convenient online submission

- Rigorous peer review

- Open access: articles freely available online

High visibility within the field

- Retaining the copyright to your article

Submit your next manuscript at $\boldsymbol{\nabla}$ springeropen.com 